\title{
The Performance of Steers Fed on Sugarcane in natura or Ensiled with Concentrate
}

\author{
Dheynne Alves Vieira ${ }^{1}$, Andréia Santos Cezário ${ }^{1}$, Wallacy Barbacena Rosa dos Santos ${ }^{1}$, Jeferson Corrêa Ribeiro ${ }^{1}$, \\ Tiago Neves Pereira Valente ${ }^{2}$, João Paulo Sampaio Rigueira ${ }^{3} \&$ Kátia Aparecida de Pinho Costa ${ }^{4}$ \\ ${ }^{1}$ Instituto Federal Goiano, Morrinhos, GO, Brazil \\ ${ }^{2}$ Instituto Federal Goiano, Posse, GO, Brazil \\ ${ }^{3}$ UEMG, Montes Claros, MG, Brazil \\ ${ }^{4}$ Instituto Federal Goiano, Rio Verde, GO, Brazil \\ Correspondence: Tiago Neves Pereira Valente, Instituto Federal Goiano, Campus Posse, GO, Rua Correntina, $\mathrm{n}^{\circ}$ \\ 824, Setor Dom Prudêncio, CEP 73900-000, Brazil. Tel: 55-64-981-097-444. E-mail: \\ tiago.valente@ifgoiano.edu.br
}

Received: January 12, $2017 \quad$ Accepted: February 8, $2017 \quad$ Online Published: February 15, 2017

doi:10.5539/jas.v9n3p226 URL: http://dx.doi.org/10.5539/jas.v9n3p226

The research is financed by Instituto Federal Goiano, Brazil.

\begin{abstract}
The aim of this study was to evaluate the performance of crossbred Holstein $\times$ Zebu steers fed on the diets containing sugarcane in natura or ensiled with two levels of concentrate (30\% and $70 \%)$. A total of 32 males of $394 \mathrm{~kg}$ of body weight were used in a completely randomized experimental design with four treatments and seven repetitions. The animals reported a high dry matter intake (DMI) $(\mathrm{P}<0.05)$ when fed on the high concentrate levels. The increase in concentrate levels resulted in an approximately $25 \%$ to $60 \%$ higher DMI as compared to the lowest level offered by silage-based diets and sugarcane in natura. The highest apparent digestibility coefficients of dry matter were observed in the diets based on sugarcane in natura $(\mathrm{P}<0.05)$. The sugarcane based diets also affected $(\mathrm{P}>0.05)$ the digestibility of organic matter, neutral detergent fiber, crude protein, ether extract, and non-fiber carbohydrates. There were no differences $(\mathrm{P}>0.05)$ between the diets for average daily weight gain, carcass dressing, carcass gain, and feed conversion. The diets based on sugarcane in nature or ensiled with $30 \%$ and $70 \%$ concentrates do not influence the performance of crossbred Holstein $\times$ Zebu cattle.
\end{abstract}

Keywords: apparent digestibility coefficients, dry matter intake, weight gain

\section{Introduction}

Sugarcane (Saccharum officinarum) is used in cattle feed in the tropical climate owing to its high production of dry materno (DM) (Silva Junior et al., 2015). Sugarcane in natura requires daily management, which increases the cost and hampers the management of the farm, especially the feedlots (Andrade, 2013; Siqueira et al., 2012). Although sugarcane silage is the main ingredient of the cattle diet in feedlots, the ensiling of sugarcane predominantly leads to alcoholic fermentation, which causes losses in its nutritional value. These losses are related to the high content of soluble carbohydrates and an increasing population of the epiphytic yeast (Mendes et al., 2008; Schmidt, 2006). In this regard, the use of numerous additives to control the population of yeast to reduce such losses is under study (Cezário et al., 2015). However, the addition of an inoculant may be unable to reduce the fermentation losses. According to Nússio and Scmidt (2005), an earlier study, reducing alcohol accumulation improves animal performance due to an increase in DMI, as a result of improved palatability to bovine. Therefore, the silage of sugarcane may result in a better animal performance when the fermentation is controlled (Queiroz et al., 2008).

The objective of this study was to evaluate the performance of Holstein $\times$ Zebu steers fed on the diets containing sugarcane in natura or ensiled with two concentrate levels. 


\section{Materials and Methods}

\subsection{Study Location}

The experiment was performed at the Experiment, Research and Extension Center of Mineiro Triangle (CEPET) in the Federal University of Viçosa (UFV) in Capinopolis city, Minas Gerais State, Brazil (average altitude of $620 \mathrm{~m}$, at $18^{\circ} 41^{\prime} 01^{\prime \prime} \mathrm{S}, 49^{\circ} 34^{\prime} 00^{\prime \prime} \mathrm{W}$ ). The climate of the region is classified as type Aw by the Köppen classification, with hot and humid summers, dry winters, and an average annual rainfall of 1200-1600 mm.

\subsection{Animal Management, Feeding, and Treatment}

In total 32 crossbred Holstein $\times$ Zebu steers with a mean initial live weight (ILW) of $394 \mathrm{~kg}$ were studied. The animals were randomly allocated into four treatment groups with seven repetitions, totaling a trial of 99 days. The animals were identified and dewormed before the beginning of the trial.

The experimental diets are shown in (Table 1). In the sugarcane silage, $0.5 \%$ of limestone was added. Diets were isoproteic and balanced to balanced to allow a daily gain of $1.0 \mathrm{~kg}$ of body weight (NRC, 1996). The animals were kept in individual pens $\left(10 \mathrm{~m}^{2}\right)$, equipped with drinkers and feeders, and with an adaptation period of 15 days to diets. During the experimental period, animals were weighed every $28 \mathrm{~d}$, after a 14-h solid food fasting to assess the mean daily weight gain (DWG). This was calculated as the difference between the latest and actual live weights divided by the number of days in the respective period.

Tabela 1. Mean chemical composition of experimental diets for organic matter (OM), crude protein (CP), ether extract (EE), non-fiber carbohydrates (NFCs), neutral detergent fiber (aNDFom-NDF), mineral matter (MM) and total carbohydrates (TC) used in different treatments

\begin{tabular}{|c|c|c|c|c|}
\hline \multirow{3}{*}{ Item } & \multicolumn{4}{|c|}{ Diets } \\
\hline & \multicolumn{2}{|c|}{ Sugarcane in natura } & \multicolumn{2}{|c|}{ Sugarcane silage } \\
\hline & $30 \%$ concentrate & $70 \%$ concentrate & $30 \%$ concentrate & $70 \%$ concentrate \\
\hline$\overline{\mathrm{OM}}$ & 93.57 & 92.92 & 93.17 & 93.02 \\
\hline $\mathrm{CP}$ & 11.69 & 11.41 & 11.83 & 11.20 \\
\hline $\mathrm{EE}$ & 3.14 & 2.72 & 3.02 & 2.67 \\
\hline MM & 6.43 & 7.08 & 6.83 & 6.98 \\
\hline aNDFom-NDF & 38.91 & 36.49 & 39.26 & 35.85 \\
\hline NFCs & 39.83 & 42.34 & 39.06 & 43.30 \\
\hline $\mathrm{TC}$ & 78.74 & 78.75 & 78.33 & 79.15 \\
\hline
\end{tabular}

Samples of the experimental diets, sugarcane, and concentrate were collected every day, and composite samples were obtained for a 28 -day period. These were placed in plastic bags and stored in a freezer $\left(-4{ }^{\circ} \mathrm{C}\right)$. After thawing, the samples of feed and forage were weighed and oven dried at $60{ }^{\circ} \mathrm{C}$ for $72 \mathrm{~h}$. Then, the samples were processed in a Wiley ${ }^{\circledR}$ knife mill, passed through 1-mm screen sieves, and stored in plastic bags. The samples were analyzed for DM, crude protein (CP), MM according to AOAC, (1990) and EE (Thiex, 2003). The samples were also checked for neutral detergent fiber (NDF) assayed with heat stable amylase and expressed exclusive of residual ash (aNDFom-NDF), acid detergent fiber expressed exclusive of residual ash (ADFom-ADF) (Van Soest \& Wine, 1967), and acid method of fiber analysis LIG (sa) (Gomes et al., 2011), after sequential extractions with neutral detergent followed by acid detergent (Van Soest, 1994). In the aNDFom-NDF analysis, a thermostable $\alpha$-amylase was used without sodium sulfite (Mertens, 2002), using an Ankom ${ }^{\circledR}$ fiber extractor (Valente et al., 2015). The total carbohydrates (TC), as proposed earlier (Sniffen et al.,1992) and non-fiber carbohydrates (NFCs) in the ingredients of the diets were determined by the following equation: $\mathrm{NFC}=100-(\% \mathrm{aNDFom}-\mathrm{NDF}+\% \mathrm{CP}$ $+\% \mathrm{EE}+\% \mathrm{MM})($ Hall, 2000).

The total digestibility nutrient (TDN) was determined as mentioned earlier (Weiss, 1999), using the following equation: TDN $=$ DCP + DaNDFom-NDF + DNFCs + 2.25DEE, where DCP stands for digestibility of crude protein); DaNDFom-NDF (digestibility of NDF); DNFCs (digestibility of non-fiber carbohydrates); DEE (digestibility of ether extract).

The apparent digestibility coefficient of nutrients with total feces collection was estimated (Schneider \& Flatt, 1975). 


\subsection{Hot Carcass Dressing}

Hot carcass dressing (HCD) was determined by calculating the ratio between hot carcass weight (HCW) (immediately after carcass trimming) and final live weight (FLW) (Lima et al., 2016) obtained at the last time when the animals were weighed after a 14-h solid food fasting (Lima et al., 2015).

\subsection{Statistical Procedures and Model Evaluation}

A completely random design with four treatments and seven repetitions was applied according to the $\mathrm{Yij}=\mu+\mathrm{Ti}$ + eij model, where Yij is the value observed in the jth experimental unit (animal) that received the ith treatment; $\mu$ is the overall mean; Ti is the fixed effect of the ith treatment; and eij is the experimental error related to the experimental unit. Data were analyzed by GLM (generalized linear models) of the SAS/STAT 9.0 software (SAS, 2001), and means were compared using Tukey's test at a 5\% significance level.

\section{Results and Discussions}

The DMI for the cattle fed on sugarcane in natura with $70 \%$ concentrate was higher $(\mathrm{P}<0.05)$ as compared to the DMI observed when the steers were fed on sugarcane silage with $30 \%$ concentrate as depicted in (Table 2). The lower DMI may be explained by the production of compounds from the anaerobic fermentation during the ensiling process, leading to a low acceptability of the feedstuff due to a strong flavor. High levels of acids in silage along with the lower concentration of soluble carbohydrates cause a reduction in the energy availability for microbial growth in the rumen, which results in decreased digestibility, thereby decreasing the passage rate and DMI of the animal (Russell, 2002; Krause et al., 2014; Valente et al., 2016).

Table 2. The intake of nutrients for cattle in feedlot fed with sugarcane in natura or sugarcane silage with two levels of concentrate in the diet

\begin{tabular}{|c|c|c|c|c|c|}
\hline \multirow{3}{*}{ Intake } & \multicolumn{5}{|c|}{ Diets } \\
\hline & \multicolumn{2}{|c|}{ Sugarcane in natura } & \multicolumn{2}{|c|}{ Sugarcane silage } & \multirow{2}{*}{$\mathrm{CV}(\%)$} \\
\hline & $30 \%$ concentrate & $70 \%$ concentrate & $30 \%$ concentrate & $70 \%$ concentrate & \\
\hline $\mathrm{DM}^{*}$ & $5.03 b$ & $8.07 \mathrm{a}$ & $4.13 b$ & $5.20 \mathrm{~b}$ & 14.79 \\
\hline $\mathrm{OM}^{*}$ & $4.70 \mathrm{~b}$ & $7.52 \mathrm{a}$ & $3.83 b$ & $4.79 b$ & 14.82 \\
\hline $\mathrm{NDF}^{*}$ & $1.35 \mathrm{~b}$ & $2.82 \mathrm{a}$ & $1.54 \mathrm{~b}$ & $2.57 \mathrm{a}$ & 13.16 \\
\hline $\mathrm{CP}^{*}$ & $0.64 b$ & $1.02 \mathrm{a}$ & $0.54 \mathrm{~b}$ & $0.67 b$ & 14.86 \\
\hline $\mathrm{EE}^{*}$ & $0.19 b$ & $0.40 \mathrm{a}$ & $0.13 b$ & $0.18 b$ & 13.57 \\
\hline $\mathrm{TC}^{*}$ & $3.87 \mathrm{~b}$ & $6.09 \mathrm{a}$ & $3.15 b$ & $3.93 b$ & 14.89 \\
\hline NFCs* & $2.52 \mathrm{a}$ & $3.26 \mathrm{a}$ & $1.61 \mathrm{~b}$ & $1.36 \mathrm{~b}$ & 16.85 \\
\hline DMI(\%BW) & $1.30 \mathrm{~b}$ & $1.93 \mathrm{a}$ & $1.02 \mathrm{~b}$ & $1.20 \mathrm{~b}$ & 16.46 \\
\hline
\end{tabular}

Note. Values with different superscripts in the same line are statistically different according to Tukey's test $(\mathrm{P}<$ $0.05) ; \mathrm{BW}=$ body weight; $\mathrm{CV}(\%)=$ coefficient of variation. ${ }^{*} \mathrm{Kg}_{\mathrm{day}}{ }^{-1}$.

The mean values of DMI $(\% \mathrm{BW})$, organic matter $(\mathrm{OM}), \mathrm{CP}$, ether extract $(\mathrm{EE})$, and TC were higher $(\mathrm{P}<0.05)$ for steers receiving the diet of sugarcane in natura with $70 \%$ concentrate. The cattle reported a higher DMI when fed on a higher level of concentrate. These results may be related to the higher digestibility of DM and consequently to the higher rate of passage due to a lower non-degradable fraction as reported by Medeiros et al. (2007). The diets with higher levels of concentrate had a higher NDF intake $(\mathrm{P}<0.05)$ in relation to the others. This could possibly be attributed to the lower content of neutral detergent fiber indigestible (NDFi) in the concentrates offered, resulting in a larger fraction of NDF potential degradability, higher digestibility, and less retention time in the rumen (Figueiras et al., 2015). A study (Rode et al., 1985) reported that increasing the concentrate and reducing the NDF levels in the diet resulted in an increased apparent digestibility of DM and OM. However, another study (Grant \& Mertens, 1992) reported that increasing the amount of concentrate may lead to reduced fiber digestion as a consequence of an increase in rapidly fermentable carbohydrates, which contradicts the findings of this study.

The diets with sugarcane in natura presented higher NFCs intake $(\mathrm{P}<0.05)$ because of higher coefficients of DM digestibility. In this direction, a study (Van Soest \& Wine, 1967) concluded that the intake of cattle may be influenced by the high availability of NFCs (98\% to 100\%). In a recent study (Missio et al., 2013), similar results were reported with higher intakes for the diets with sugarcane in natura in relation to the diets with hydrolyzed sugarcane with different storage times. 
In a similar study on intake, the cattle fed on sugarcane in natura and silage (Mariz et al., 2013) reported differences in the intake of CP, EE, NDF, and NFCs but no difference for DM, \%BW, and MO. Another study (Santos et al., 2011) reported the effect of diet on all intakes measured, except for the intake of ether extract. The animals fed on sugarcane in natura presented greater nutrient intake as well as better dry matter digestibility, ether extract, and TDN content, and a superior performance in relation to the animals fed on ensilaged sugarcane diets (Menezes et al., 2011). The diets based on sugarcane in natura presented a higher $(\mathrm{P}<0.05)$ apparent digestibility of dry matter (DDM). The (Table 3) shows the mean values for nutrient digestibility and their respective coefficients of variation. A study (Pedroso et al., 2005) reported that about $68 \%$ of the soluble carbohydrates are consumed during the silage process. The ensiling process reduces the constituents of the cell wall, which results in low digestibility (Coan et al., 2002). According to Landell et al. (2002), the voluntary intake is inversely related to the NDF content of sugarcane and its digestibility. A similar value was observed (Menezes et al., 2011) for the digestibility of dry matter (DDM) of sugarcane in natura (68.08\%) and a higher value for silage sugarcane $(61.26 \%)$ than obtained in this study.

Table 3. Mean values for nutrient digestibility, total digestibility nutrient (TDN), and their respective coefficients of variation for steers fed with sugarcane in natura ou ensiled.

\begin{tabular}{|c|c|c|c|c|c|c|}
\hline \multirow{3}{*}{ Item* } & \multicolumn{6}{|c|}{ Diets } \\
\hline & \multicolumn{2}{|c|}{ Sugarcane in natura } & \multicolumn{2}{|c|}{ Sugarcane silage } & \multirow{2}{*}{ Mean } & \multirow{2}{*}{$\mathrm{CV}(\%)$} \\
\hline & $30 \%$ concentrate & $70 \%$ concentrate & $30 \%$ concentrate & $70 \%$ concentrate & & \\
\hline DDM & $66.43 \mathrm{ab}$ & $69.35 \mathrm{a}$ & $56.41 \mathrm{c}$ & $57.42 b c$ & 62.40 & 7.64 \\
\hline DOM & 78.97 & 72.62 & 77.99 & 67.15 & 74.18 & 13.21 \\
\hline DaNDFom-NDF & 42.97 & 50.67 & 57.80 & 47.35 & 49.70 & 24.30 \\
\hline DCP & 82.09 & 77.90 & 82.21 & 76.73 & 79.74 & 10.93 \\
\hline DEE & 92.56 & 79.62 & 84.19 & 77.25 & 83.40 & 15.63 \\
\hline DTC & 78.40 & 75.58 & 77.96 & 70.56 & 75.62 & 12.53 \\
\hline DNFCs & 83.82 & 87.96 & 83.97 & 82.63 & 84.60 & 11.88 \\
\hline TDN & 65.11 & 66.71 & 70.23 & 63.15 & 66.30 & 13.04 \\
\hline
\end{tabular}

Note. The values with different superscripts in the same row are statistically different according to Tukey's test ( $\mathrm{P}$ $<0.05) ; * \% \mathrm{DM}$.

There were no differences $(\mathrm{P}>0.05)$ in the digestibility coefficients of the OM, NDF, CP, EE, NFCs, TC, and TDN as shown in Table 3. These results reflected similarities between the feedstuffs in experimental diets (Table 1) and no difference $(\mathrm{P}>0.05)$ for the DMO as presented in (Table 3$)$.

There was no effect of the treatments $(\mathrm{P}>0.05)$ on daily weight gain (DWG), hot carcass dressing (HCD), carcass gain, and feed conversion (Table 4). The mean for DWG was $0.79 \mathrm{~kg}^{-1} \mathrm{day}^{-1}$. The mean values for HCD, carcass gain, and feed conversion were $53.32 \%, 0.38 \mathrm{~kg} \mathrm{day}^{-1}$ and 9.35 , respectively. A similar observation was made for Nellore cattle (Missio et al., 2013) with DWG $=0.79 \mathrm{~kg} \mathrm{day}^{-1}$ for a diet with sugarcane in natura. However, a feed conversion of 4.77 was observed, which is better than that reported in the current study. In another study, Roman et al. (2011) observed higher average values for DWG and feed conversion (1.39 and 7.7 respectively), and similar values for $\mathrm{HCD}$ for sugarcane silage.

Table 4. The performance and feed efficiency of cattle fed with sugarcane in natura ou ensiled

\begin{tabular}{|c|c|c|c|c|c|c|}
\hline \multirow{3}{*}{ Animal Performance } & \multicolumn{6}{|c|}{ Diets } \\
\hline & \multicolumn{2}{|c|}{ Sugarcane in natura } & \multicolumn{2}{|c|}{ Sugarcane silage } & \multirow{2}{*}{ Mean } & \multirow{2}{*}{$\mathrm{CV}(\%)$} \\
\hline & $30 \%$ concentrate & $70 \%$ concentrate & $30 \%$ concentrate & $70 \%$ concentrate & & \\
\hline DWG $\left(\mathrm{Kg} \mathrm{day}^{-1}\right)$ & 0.82 & 0.72 & 0.76 & 0.87 & 0.79 & 61.23 \\
\hline $\operatorname{HCD}(\%)$ & 52.33 & 52.73 & 54.60 & 53.63 & 53.32 & 3.34 \\
\hline Carcass gain $\left(\mathrm{Kg} \mathrm{day}^{-1}\right)$ & 0.35 & 0.31 & 0.42 & 0.43 & 0.38 & 86.74 \\
\hline Feed conversion (Kg DMI/kg gain) & 9.18 & 12.91 & 7.40 & 7.90 & 9.35 & 56.29 \\
\hline
\end{tabular}

Note. No statistical differences were found according to Tukey's test $(\mathrm{P}<0.05)$. 
The carcass gains $(\mathrm{kg} / \mathrm{day})$ were approximately $26 \%$ greater $(0.65 \times 0.52)$ for the animals fed on sugarcane in natura than the diets with ensilaged sugarcane (Menezes et al., 2011). The major problem with ensilaged sugarcane is its high content of soluble carbohydrates and a high population of epiphytic yeast, which lead to alcoholic fermentation. During the ensiling of sugarcane, an excessive loss of dry matter occurs, which is reflected in terms of animal performance. However, the evaluation of empty body weight (Macitelli et al., 2005) indicated that the beef cattle fed on sugarcane had higher weights of stomach and gastrointestinal contents, resulting in a lower empty body weight for these animals, a fact possibly could be explained by the inferior quality of NDF of the sugarcane and its greater content of NDFi in relation to the other grasses that composed the diet. However, no improvement in the performance of the animals was observed (Abrahão et al., 2007) when fed on sugarcane in natura, not even with a higher concentrate in the diet.

\section{Conclusion}

The diets based on sugarcane in nature or ensiled with $30 \%$ and $70 \%$ concentrates do not influence the performance of crossbred Holstein $\times$ Zebu cattle.

\section{References}

Abrahão, J. J. S., Marques, J. A., \& Pinto A. P. (2007). Desempenho de tourinhos mestiços confinados submetidos a dietas com cana-de-açúcar em substituição à silagem de sorgo. Reunião anual da sociedade brasileira de zootecnia (Anais... Jaboticabal: SBZ, 2007).

Andrade, F. L. (2013). Silagem de cana-de-açúcar para vacas em lactação (Master's thesis). Curso de Pós-graduação em Zootecnia, Universidade Federal de Viçosa, Viçosa, Brazil.

AOAC. (1990). Official Methods of Analysis (15th ed.). Association of Official Analytical Chemists, Arlington, VA.

Cezário, A. S., Ribeiro, K. G., Santos, S. A., Valadares Filho, S. C., \& Pereira, O. G. (2015). Silages of Brachiaria brizantha cv. Marandu harvested at two regrowth ages: Microbial inoculant responses in silage fermentation, ruminant digestion and beef cattle performance. Anim. Feed Sci. and Technol., 208, 33-43. https://doi.org/ 10.1016/j.anifeedsci.2015.06.025

Coan, R. M., Silveira, R. N., \& Bernardes, T. F. (2002). Composição química da cana-de-açúcar crua ou queimada ensilada com aditivo. Reunião anual da sociedade brasileira de zootecnia (Anais... Recife: SBZ, 2002).

Figueiras, J. F., Detmann, E., Valadares Filho, S. C., Paulino, M. F., Batista, E. D., Rufino, L. M. A., ... Franco, M. O. (2015). Desempenho nutricional de bovinos em pastejo durante o período de transição seca-águas recebendo suplementação protéica. Arch. Zootec., 64, 269-276.

Gomes, D. I., Detmann, E., Valadares Filho, S. C., Fukushima, R. S., Souza, M. A., Valente, T. N. P., \& Queiroz, A. C. (2011). Evaluation of lignin contents in tropical forages using different analytical methods and their correlations with degradation of insoluble fiber. Anim. Feed Sci. Technol., 168, 206-222. https://doi.org/10.1016/j.anifeedsci.2011.05.001

Grant, R. J., \& Mertens, D. R. (1992). Development of buffer systen for $\mathrm{pH}$ control and evaluation of ph effects on fiber digestion in vitro. Journal Dairy Science, 75, 1581-1587. https://doi.org/10.3168/jds.S0022-0302 (92)77915-6

Hall, M. B. (2000). Calculation of no-structural carbohydrate content of feeds that contain no-protein nitrogen (p. A-25, Bulletin, 339). University of Florida.

Krause, D. O., Nagaraja, T. G., Wright, A. D., \& Callaway, T. R. (2014). Board-invited review: Rumen microbiology: Leading the way in microbial ecology. J. Anim. Sci., 91, 331-334. https://doi.org/10.2527/jas.2012-5567

Landell, M. G. A., Campana, M. P., \& Rodrigues, A. A. (2002). A variedade IAC86-2480 como nova opção de cana-de-açúcar para fins forrageiros: Manejo de produção de uso na alimentação animal (Série Tecnologia APTA, boletim técnico IAC, 193, p. 39). Instituto Agronômico.

Lima, E. S., Morais, J. P. G., Roça, R. O., Costa, Q. P. B., Andrade, E. N., Vaz, V. P., Valente, T. N. P., \& Costa, D. P. B. (2015). Meat characteristics of Nellore cattle fed different levels of lipid-based diets. J. Agric. Sci., 7, 174-183. https://doi.org/10.5539/jas.v7n7p174

Lima, E. S., Morais, J. P. G., Roça, R. O., Valente, T. N. P., Andrade, E. N., \& Deminicis, B. B. (2016). Performance and carcass characteristics of cattle fed lipid sources in the diet. Can. J. Anim. Sci., 96, 581-588. https://doi.org/10.1139/cjas-2015-0203 
Macitelli, F., Berchielli, T. T., Silveira, R. N., Andrade, P., Lopes, A. D., Sato, K. J., \& Barbosa, J. C. (2005). Biometria da carcaça e peso de vísceras e de órgãos internos de bovinos mestiços alimentados com diferentes volumosos e fontes protéicas. Bras. J. Anim. Sci., 34, 1751-1762. https://doi.org/10.1590/s1516-359820050 00500037

Mariz, L. D. S., Valadares Filho, S. C., Detmann, E., Pereira, O. G., Marcondes, M. I., Santos, S. A., ... Nunes, A. N. (2013). Intake and ruminal digestion determined using omasal and reticular digesta samples in cattle fed diets containing sugar cane in natura or ensiled sugar cane compared with maize silage. Livestock Science, 155, 71-76. https://doi.org/10.1016/j.livsci.2013.04.003

Medeiros, G. R., Carvalho, F. F. R., Ferreira, M. A., Batista, A. M. V., Alves, K. S., Maior Júnior, R. J. S., \& Almeida, S. C. (2007). Efeito dos níveis de concentrado sobre o desempenho de ovinos Morada Nova em confinamento. Bras. J. Anim. Sci., 36, 1162-1171. https://dx.doi.org/10.1590/S1516-35982007000500025

Mendes, C. Q., Susin, I., Nussio, L. G., Pires, A. V., Rodrigues, G. H., \& Urano, F. S. (2008). Efeito do Lactobacillus buchneri na fermentação, estabilidade aeróbia e no valor nutritivo de silagem de cana-de-açúcar. Bras. J. Anim. Sci., 37, 2191-2198. https://dx.doi.org/10.1590/S1516-35982008001200017

Menezes, G. C. C., Valadares Filho, S. C., Magalhães, F. A., Valadares, R. F. D., Prados, L. F., Detmann, E., Pereira, O. G., \& Leão, M. I. (2011). Intake and performance of confined bovine fed fresh or ensilaged sugar cane based diets and corn silage. Bras. J. Anim. Sci., 40, 1095-1103. https://dx.doi.org/10.1590/S1516-35982011000500022

Mertens, D. R. (2002). Gravimetric determination of amylase-treated neutral detergent fiber in feeds with refluxing in beaker or crucibles: Collaborative study. J AOAC Int, 85, 1217-1240.

Missio, R. L., Oliveira, M. D. S., Sforcini, M. P. R., Restle, J., Elejalde, D. A. G., Ferrari, V. B., \& Abud, G. C. (2013). Consumo de matéria seca e desempenho de novilhas Nelore alimentadas com dietas contendo cana-de-açúcar hidrolisada. Ciência Rural, 43, 1050-1056. https://doi.org/10.1590/S0103-8478201300 5000069

NRC. (1996). Nutrient requirements of dairy cattle (p. 242). Wahington, D. C. National Academy.

Nússio, L.G., \& Schmidt, P. (2005). Silagens de cana-de-açúcar para bovinos leiteiros: aspectos agronômicos e nutricionais. Simpósio sobre bovinocultura leiteira (pp. 193-218). Piracicaba. Visão técnica e econômica da produção leiteira: Anais... Piracicaba.

Pedroso, A. F., Nussio, L. G., Paziani, S. F., Loures, D. R. S., Igarasi, M. S., Coelho, R. M., ... Gomes, L. H. (2005). Fermentation and epiphytic microflora dynamics in sugar cane silage. Scientia Agricola, 62, 427-432.https://dx.doi.org/10.1590/S0103-90162005000500003

Queiroz, O. C. M., Nussio, L. G., Schmidt, P., Ribeiro, J. L., Santos, M. C., \& Zopollatto, M. (2008). Silagem de cana-de-açúcar comparada a fontes tradicionais de volumosos suplementares no desempenho de vacas de alta produção. Bras. J. Anim. Sci., 37, 358-365. http://dx.doi.org/10.1590/S1516-35982008000200024

Rode, L. M., Weakley, D. C., \& Satter, L. D. (1985). Effect of forage amount and particle size in diets of lactating dairy cows on site of digestion and microbial synthesis. Canadian Journal of Animal Science, 65, 101-11. https://doi.org/10.4141/cjas85-011

Roman, J., Jobim, C. C., Resende, F. D., Siqueira, G. R., Faria, M. H., \& Oliveira Neto, R. A. (2011). Performance of finishing beef cattle fed different diets containing whole-crop maize silage or sugarcane silage. Bras. $J$. Anim. Sci., 40, 682-689. https://dx.doi.org/10.1590/S1516-35982011000300029

Russell, J. B. (2002). Rumen Microbiology and its role in ruminant nutrition (p. 119). Ithaca, NY.

Santos, S. A., Valadares Filho, S. C., Detmann, E., Valadares, R. F. D., Ruas, J. R. M., \& Amaral, P. M. (2011). Different forage sources for F1 Holstein $\times$ Gir dairy cows. Livestock Science, 142, 48-58. https://doi.org/10.1016/j.livsci.2011.06.017

SAS. (2001). Statistical analysis system - sas. User's guide: statistics. Cary: SAS Institute.

Schmidt, P. (2006). Perdas fermentativas na ensilagem, parâmetros digestivos e desempenho de bovinos de corte a calcium oxidentados com rações contendo silagem de cana de açúcar (Ph.D. thesis). Escola Superior de Agricultura Luiz de Queiroz/Universidade de São Paulo, Piracicaba, Brazil.

Schneider, B. H., \& Flatt, W. P. (1975). The evaluation of feeds through digestibility experiments (p. 423). Athens: University of Georgia Press. 
Silva Junior, B. A., Oliveira, M. V. M., Maltempi Filho, P., Luz, D. F., Sterza, F. A. M., Vargas Junior, F. M., \& Biazolli, W. (2015). Desempenho de vacas leiteiras alimentadas com cana-de-açúcar associada à ureia e tratada com cal virgem na região do Alto Pantanal Sul-Mato-Grossense. Semina, 2317-2328.

Siqueira, G. R., Roth, M. T. P., Moretti, M. H., Benatti, J. M. B., \& Resende, F. D. (2012). Uso da cana-de-açúcar na alimentação de ruminantes. Revista Brasileira Saúde Produção Animal, 13, 991-1008. https://doi.org/10.1590/S1519-99402012000400011

Sniffen, C. J., O’Connor, J. D., Van Soest, P. J., Fox, D. G., \& Russell, J. B. (1992). A net carbohydrate and protein system for evaluating cattle diets: II. Carbohydrate and protein availability. Journal of Animal Science, 70, 3562-3577. https://doi.org/10.2527/1992.70113562x

Thiex, N. J., Anderson, S., \& Gildemeister, B. (2003). Crude fat, hexanes extraction, in feed, cereal grain, and forage (Randall/Soxtec/submersion method): Collaborative study. J. AOAC Int., 86, 899-908.

Valente, T. N. P., Detmann, E., \& Sampaio, C. B. (2015). Review: Recent advances in evaluation of bags made from different textiles used in situ ruminal degradation. Canadian Journal of Animal Science, 95, 493-498. https://doi.org/10.4141/cjas-2015-100

Valente, T. N. P., Lima, E. S., Santos, W. B. R., Cesário, A. S., Tavares, C. J., Fernandes, I. L., \& Freitas, M. A. M. (2016). Ruminal microorganism consideration and protein used in the metabolism of the ruminants: A Review. African Journal Microbiology Research, 10, 456-464. https://doi.org/10.5897/AJMR2016.7627

Van Soest, P. J. (1994). Nutritional ecology of the ruminant (2nd ed., p. 476). Ithaca: Cornell University Press.

Van Soest, P. J., \& Wine, R. H. (1967). Use of detergents in the analysis of fibrous feeds. IV Determination of plant cell-wall constituents. Journal of the Official Agricultural Chemist., 50, 50-55.

Weiss, W. P. (1999). Energy prediction equations for ruminant feeds. Proceedings of Cornell Nutrition Conference for Feed Manufacturers (pp.176-185). Ithaca: Cornell University.

\begin{abstract}
Abbreviations
ADFom-ADF, acid detergent fiber expressed exclusive of residual ash; aNDFom-NDF, neutral detergent fiber assayed with a heat stable amylase and expressed exclusive of residual ash; aNDFom-NDFI, NDF intake; BW, body weight; CP, crude protein; CPI, crude protein intake; DaNDFom-NDF, digestibility of NDF; DCP, digestibility of crude protein; DEE, digestibility of ether extract; DDM, digestibility of dry matter; DNFCs, digestibility of non-fibrous carbohydrates; DM, dry matter; DMI, dry matter intake; DNFCs, digestibility of non-fiber carbohydrates; DTC, digestibility of total carbohydrates; DWG, daily weight gain; EE, ether extract; HCD, hot carcass dressing; HCW, hot carcass weight; ILW, initial live weight; LIG(sa), lignin determined by solubilization of cellulose with sulfuric acid; MM, mineral matter; NDFi, neutral detergent fiber indigestible; NFCs, non-fibrous carbohydrates; OM, organic matter; TC, total carbohydrates; TDN, total digestibility nutrient.
\end{abstract}

\title{
Copyrights
}

Copyright for this article is retained by the author(s), with first publication rights granted to the journal.

This is an open-access article distributed under the terms and conditions of the Creative Commons Attribution license (http://creativecommons.org/licenses/by/4.0/). 